Kamil Weber

ORCID: 0000-0002-6904-0073

Uniwersytet Opolski

\title{
Rola tradycji konfucjańskich w umacnianiu współczesnego reżimu politycznego Koreańskiej Republiki Ludowo-Demokratycznej
}

DOI: $10.19195 / 1643-0328.26 .3$

Słowa kluczowe: Korea Północna, konfucjanizm, reżim, Kim Jong-un

\section{Wprowadzenie}

W państwach azjatyckich autorytarny charakter relacji był zauważalny od wieków, na gruncie nie tylko politycznym, lecz także społecznym. Spore znaczenie w tym względzie miał upowszechniony tam konfucjanizm. Zdaniem wielu autorów specjalizujących się w tematyce politologicznej Azji, wywodzące się z tej ideologii poglądy nadal wywierają znaczący wpływ na mentalność mieszkańców Koreańskiej Republiki Ludowo-Demokratycznej (KRLD) oraz oddziałują na tamtejszy system polityczny. Pojawiają się jednak opinie, według których określanie tego państwa jako konfucjańskiego jest sporym błędem, gdyż w wielu aspektach panująca tam sytuacja zaprzecza wytycznym tego systemu filozoficznego. Takie opinie przejawia między innymi wybitny koreanista Brian Reynolds Myers. Analiza rzeczywistego znaczenia konfucjanizmu w obecnych uwarunkowaniach północnokoreańskich jest o tyle istotna, o ile niektóre wartości i postulaty, które mają swe źródło w tej ideologii, mogą mieć znaczący, jeśli nie determinujący, wpływ na umacnianie i zachowanie trwałości reżimu Kim Jong-una. Artykuł ten ma wobec tego ukazać rzeczywiste znaczenie wytycznych tego nurtu w Korei Północnej. Należy zatem odpowiedzieć na pytania dotyczące tego, jakie są źródła tradycji konfucjańskich w tym państwie oraz które ich elementy obecnie zostały zachowane. Nastąpi to poprzez wykazanie podobieństw obecnej sytuacji do założeń konfucjanizmu oraz opisanie zaprzeczeń względem wytycznych tej ideologii. Przeanalizowane zostanie także to, jak tradycje te są wykorzystywane przez północnokoreańskie władze oraz w jaki sposób może to decydować o przyszłości reżimu politycznego panującego w Pjongjang. 
Ze względu na określony zakres rozważań do przeprowadzenia analizy niezbędna wydaje się historyczna metoda badawcza ${ }^{1}$. Umożliwi ona ukazanie genezy zjawisk i procesów, które obecnie mają znaczący wpływ na kształt i funkcjonowanie reżimu północnokoreańskiego. Metoda porównawcza umożliwi z kolei zestawianie z sobą wydarzeń $\mathrm{z}$ różnych okresów oraz odnajdowanie analogii między sytuacją w KRLD i innych państwach. Trzecią zastosowaną metodą badawczą będzie metoda ekstrapolacji umożliwiająca prognozowanie przybliżonego kierunku rozwoju zjawisk politycznych na bazie analizy dotychczasowych wydarzeń.

\section{Umacnianie wpływów konfucjanizmu na terenie Korei oraz jego podstawowe wytyczne}

Konfucjanizm jako nurt intelektualny i duchowy powstał około 500 lat p.n.e., stając się podstawą rozwoju cywilizacji chińskiej ${ }^{2}$. Swoją dojrzałość osiągnął za panowania dynastii Han (206 rok p.n.e.-220 rok n.e.) $)^{3}$. Upowszechniał się również w Japonii, Wietnamie i innych krajach Azji ${ }^{4}$ Na terenie Półwyspu Koreańskiego pojawił się w IV wieku n.e. Miał wielki wpływ na życie moralne, intelektualne i polityczne jego mieszkańców. W Królestwie Koguryo już w 372 roku powstał Uniwersytet Konfucjański ${ }^{5}$. Od VI wieku następowało przenikanie i uzupełnianie się konfucjanizmu i buddyzmu ${ }^{6}$. Konfucjanizm odnosił się do wartości moralnych, porządku społecznego i ustroju politycznego. Buddyzm z kolei wzbogacał te poglądy o elementy duchowe i religijne, bardziej skupiając się na kwestiach natury człowieka i właściwego sposobu życia ${ }^{7}$.

Początkowo konfucjanizm był w większym stopniu traktowany jako doktryna filozoficzna niż religia. Charakter systemu wierzeń nadała mu dopiero dynastia Chosun ${ }^{8}$, która wykorzystała go do umacniania swojej legitymizacji politycznej ${ }^{9}$. W okresie ich panowania nastąpił rozkwit tej ideologii. W roku 1392 miało miejsce przeniesienie stolicy z Kaesong do Hansung, czyli dzisiejszego Seulu. Przyjęto wtedy konfucjanizm jako religię państwową, wobec czego dotychczasowy wpływ buddyzmu został znacznie ograniczony ${ }^{10}$. Rozwijanie konfucjańskich norm oraz tworzenie się opartych na nich struk-

1 J. Kukułka, Teoria stosunków międzynarodowych, Warszawa 2000, s. 167-168.

2 N. Levi, System polityczny Korei Pótnocnej. Aspekty kulturowe, Warszawa 2013, s. 14.

${ }^{3}$ K. Gawlikowski, Jednostka i władza w cywilizacji wschodnioazjatyckiej, [w:] Korea: doświadczenia i perspektywy, red. K. Gawlikowski, E. Potocka, Toruń 2002, s. 31.

${ }^{4}$ N. Levi, op. cit., s. 14.

5 G. Strnad, Korea. Polityka Południa wobec Pólnocy w latach 1948-2008. Zmiana i kontynuacja, Poznań 2014, s. 92.

${ }^{6}$ N. Levi, op. cit., s. 17.

7 K. Gawlikowski, op. cit., s. 30.

${ }^{8}$ Dynastia ta rządziła Koreą od końca XIV wieku do 1910 roku.

9 T. Goban-Klas, Historia i współczesność Korei. Od pustelniczego królestwa do azjatyckiego tygrysa, Toruń 2006, s. 114.

10 N. Levi, op. cit., s. 19. 
tur społecznych i politycznych było procesem długotrwałym i zakończyło się w Korei na początku XIX wieku ${ }^{11}$.

Upowszechniająca się doktryna promowała między innymi zorientowanie na tradycję, szacunek dla edukacji, utrzymywanie konsensusu społecznego i silne przywództwo ${ }^{12}$. Akcentowany był patriarchalizm, który przenikał się z kulturą koreańską, zakładając pionowe stosunki społeczne i polityczne ${ }^{13}$. Postulowano przypisanie jednostkom sztywnej roli w hierarchii oraz podporządkowanie się rodzicom, władzy, starszym i zwierzchnikom $^{14}$. Wzory kulturowe zakorzenione $\mathrm{w}$ konfucjanizmie podkreślają także znaczenie harmonii oraz politycznego porządku ${ }^{15}$. Preferowane były powolne zmiany w państwie i społeczeństwie, ostrożność, zapobiegliwość i poszukiwanie kompromisowych rozwiązań $^{16}$. Zgodnie z duchem konfucjanizmu i buddyzmu człowiek powinien wypełniać swoje obowiązki bez względu na poświęcenie i cierpienie, a nawet za cenę życia ${ }^{17}$.

Konfucjanizm szczególne znaczenie przypisywał rodzinie, która pełniła najważniejszą rolę w życiu jednostki. Była ona gloryfikowana jako doskonała forma społecznej wspólnoty, stanowiąca źródło tożsamości każdej osoby ${ }^{18}$. W dawnej Korei wszyscy zobowiązani byli do okazywania szacunku względem rodziców. Podstawową wartością konfucjanizmu było xiao, czyli cnota posłuszeństwa wobec nich. Za jej złamanie karano nawet śmiercią $^{19}$. Dlatego kluczowe znaczenie miało synowskie oddanie i podporządkowanie głowie $\operatorname{rodu}^{20}$. Ojciec cieszył się zatem powszechnym autorytetem ${ }^{21}$. Syn był zobowiązany do miłości względem ojca, natomiast ten do dobroci i opieki wobec swojego potomka ${ }^{22}$. Najstarszy z braci uważany był za naturalnego następcę w tej roli. Po śmierci ojca dziedziczył on nie tylko poważanie i majątek, lecz także kultywował pielęgnowane przez przodków wartości. Taki model więzi autorytarno-rodzinnych między rodzicami i dziećmi został zaadaptowany również do systemu rządzenia ${ }^{23}$.

\section{Konfucjanizm a model sprawowania władzy}

W systemach politycznych ukształtowanych pod wpływem konfucjanizmu nacisk kładziony był na nadrzędną rolę władcy, paternalizm i autorytaryzm odwołujący się do

11 K. Gawlikowski, op. cit., s. 31.

12 T. Goban-Klas, op. cit., s. 116-117.

13 N. Levi, op. cit., s. 15.

14 T. Goban-Klas, op. cit., s. 116-117.

15 G. Strnad, op. cit., s. 93.

16 T. Goban-Klas, op. cit., s. 116-117.

17 K. Gawlikowski, op. cit., s. 47.

18 G. Strnad, op. cit., s. 98.

19 K. Gawlikowski, op. cit., s. 48.

${ }^{20}$ H. Nakamura, Systemy myślenia ludów Wschodu. Indie, Chiny, Tybet, Japonia, przeł. M. Kanert, W. Szkudlarczyk-Brkić, red. P.P. Wiener, Kraków 2005, s. 266.

${ }^{21}$ N. Levi, op. cit., s. 15.

22 G. Strnad, op. cit., s. 98.

23 N. Levi, op. cit., s. 15-16. 
sformalizowanych struktur podległości ${ }^{24}$. Akcentowano pozycję władz i uzasadniano konieczność ich istnienia ${ }^{25}$. Moralność i polityka miały łączyć się z sobą w ścisły sposób ze względu na związek między interesem własnym, rodziny, społeczności i narodu ${ }^{26}$. Respekt i podporządkowanie syna względem ojca przekładały się na podobną relację między poddanym a władcą ${ }^{27}$. Stosunki te miały zatem charakteryzować się oddaniem i posłuszeństwem ${ }^{28}$. Rodziny były zobowiązane do uległości względem władcy, natomiast ten był odpowiedzialny za takie zorganizowanie państwa, by nie musiały one działać wbrew swojemu interesowi ${ }^{29}$. Silny szacunek dla cesarza miał swoje źródła w tradycyjnym umiłowaniu porządku. Zgodnie z „teorią panowania niebios” to właśnie niebiosa (Tian) dawały cesarzowi prawo rządzenia. Miał on też otrzymywać z nich moc i dzięki temu zyskiwał nawet większy autorytet niż niektóre istoty boskie $\mathrm{z}$ wierzeń ludowych ${ }^{30}$.

Przywódca miał pełnić funkcję nie tylko lidera politycznego, lecz także nauczyciela narodu. Władca konfucjański był duchowym i świeckim przewodnikiem, prawodawcą, twórcą obowiązujących wartości i uchodził za najdoskonalszego z ludzi. Jego cnoty zapewniały mu podporządkowanie i poparcie poddanych ${ }^{31}$. Często sam był postrzegany jako bóstwo ${ }^{32}$. Z natury rzeczy był osobą rozkazującą, a poddani - posłusznie wykonującymi jego polecenia ${ }^{33}$. Ponosił przy tym pełną odpowiedzialność za podległych mu ludzi, a przede wszystkim za harmonię wśród nich ${ }^{34}$. Konfucjusz twierdził, że władze mogą panować przy użyciu praw i kar, jednak nie uważał tego za najwłaściwszy sposób rządzenia. Mówił o rodzaju charyzmy zwanej De, która zapewniała dobrowolne posłuszeństwo poddanych bez potrzeby uciekania się do przymusu ${ }^{35}$. W społecznościach konfucjańskich dopiero gdy łagodne środki kontroli społecznej okazywały się niewystarczające, następowało odwołanie się do $\mathrm{kar}^{36}$. Postulowana była przy tym troska o każdą jednostkę 37 .

Według tradycji konfucjańskiej przywódca zyskiwał możliwość rządzenia na skutek swoich cech i zdolności. Uważany był za osobę, której przypadła taka rola, ponieważ był jej najgodniejszy. Jego potomkowie tracili jednak możliwość sprawowania władzy, jeśli

24 G. Strnad, op. cit., s. 98.

25 H. Nakamura, op. cit., s. 263.

26 G. Strnad, op. cit., s. 93.

27 Szerzej zob. K.K. Lee, Confucian Tradition in the Contemporary Korean Family, [w:] Confucianism and the Family: A Study of Indo-Tibetan Scholasticism, red. W.H. Slote, G.A. De Vos, New York 1998, s. 252.

28 H. Lee, Kapitalizm konfucjański. Koreańska droga rozwoju, Toruń 2011, s. 38.

29 Z. Wesołowski, Konfucjańskie podstawy porządku społecznego i zjawisko „twarzy”, [w:] Zrozumieć Chińczyków. Kulturowe kody społeczności chińskich, red. E. Zajdler, Warszawa 2011, s. 185.

30 H. Nakamura, op. cit., s. 268.

31 G. Strnad, op. cit., s. 99.

32 K. Gawlikowski, op. cit., s. 58.

33 Z. Wesołowski, op. cit., s. 184.

34 K. Gawlikowski, op. cit., s. 59.

35 H. Lee, op. cit., s. 32.

36 Ibidem, s. 39.

37 Z. Wesołowski, op. cit., s. 187. 
nie wykazywali podobnych zalet ${ }^{38}$. Według konfucjanizmu cnoty nie były dziedziczone, lecz osiągane dzięki edukacji etycznej i moralnej ${ }^{39}$. Konfucjusz argumentował jednak, że książę (junzi) jako syn władcy, który kultywuje jego wartości, jest osobą mogącą doprowadzić naród do harmonii. Wszyscy poddani mogą z kolei uważać się za naśladowców księcia, jeśli odpowiednio postępują i kształtują swoją osobowość ${ }^{40}$.

Nurt ten precyzował też kształt stosunków społecznych i sposób funkcjonowania społeczeństwa. Zgodnie z jego wytycznymi każdy człowiek rodził się w hierarchicznej strukturze relacji interpersonalnych ${ }^{41}$. Nawet azjatyckie mity dotyczące początków człowieka zazwyczaj mówią raczej o pojawieniu się zbiorowości, a nie pojedynczej postaci ${ }^{42}$. System ten zakłada zatem traktowanie jednostki jako części grupy, którą ona współtworzy, a nie autonomicznego podmiotu. Dobro ogółu było wartością nadrzędną ${ }^{43}$. Konfucjanizm zakładał niwelowanie egoistycznych tendencji i dążeń indywidualnych, promując $\mathrm{w}$ ich miejsce dostosowanie się do świata i tworzenie $\mathrm{z}$ nim harmonii ${ }^{44}$. Z kolei osoba skupiająca się jedynie na własnych przyjemnościach i szczęściu była uważana za prymitywną ${ }^{45}$. Zatem jednostka miała być ukierunkowana raczej na zobowiązania wobec innych członków grupy niż na swoje prawa. Dzięki temu przyczyniała się do realizowania celów wspólnoty ${ }^{46}$. Wobec tego za najważniejszą cechę systemu społecznego uchodził kolektywizm. Przejawem tego był również fakt, że za przewinienia danej osoby winę ponosiła cała rodzina ze względu na nieodpowiednie wychowanie tego, kto łamał przyjęte normy ${ }^{47}$. System stosunków rodzinnych był w pewien sposób rozciągnięty na naród i sferę polityki ${ }^{48}$. Rodzina była traktowana jako idealny model wspólnoty politycznej ${ }^{49}$. Społeczeństwo postrzegano wobec tego jako jedną dużą rodzinę podporządkowaną władcy ${ }^{50}$. Ponadto role narodu i rodziny wzajemnie się uzupełniały. Rodziny potrzebowały opieki ze strony narodu, bez rodzin natomiast żaden naród nie mógłby powstać, gdyż były one podstawowymi komórkami, które go budują ${ }^{51}$. We współczesnych Chinach, Japonii i Korei państwo nadal powszechnie uważane jest za zbiór rodzin, a nie jak w cywilizacji zachodniej — zbiór jednostek ${ }^{52}$.

38 K. Gawlikowski, op. cit., s. 61.

39 H. Lee, op. cit., s. 35.

40 N. Levi, The Impact of Confucianism in South Korea and Japan, „Acta Asiatica Varsoviensia” 2013, nr 26, s. 8.

41 G. Strnad, op. cit., s. 93.

42 K. Gawlikowski, op. cit., s. 35.

43 N. Levi, System polityczny Korei..., s. 16.

44 H. Nakamura, op. cit., s. 266.

45 K. Gawlikowski, op. cit., s. 47.

46 Ibidem, s. 63.

47 N. Levi, System polityczny Korei..., s. 21.

48 H. Nakamura, op. cit., s. 266.

49 G. Strnad, op. cit., s. 98.

50 N. Levi, System polityczny Korei..., s. 15.

51 H. Lee, op. cit., s. 45.

52 T. Sleziak, The Role of Confucianism in Contemporary South Korean Society, „Rocznik Orientalistyczny” 66, 2013, z. 1, s. 35 . 
W tradycji konfucjańskiej państwo traktowane było jako organizator życia społecznego, gospodarczego i intelektualnego, kontrolując też wychowanie moralne poddanych. W praktyce jednak to najczęściej wielkie rody zarządzały jednostkami, mając bardzo rozbudowane uprawnienia. Rola państwa ograniczała się raczej do nadzorowania. Trudno było zatem oczekiwać rozwoju koncepcji praw obywatelskich, ograniczających uprawnienia władzy państwowej ${ }^{53}$. Ponadto w Europie wolność rozumiano jako swobodę w realizacji własnych celów i likwidację ograniczeń. Była zatem skierowana na zewnątrz jednostki. W Chinach wolność pojmowano wewnętrznie - jako pokonywanie własnych ograniczeń i słabości. Chou Yang-sun — współczesny tajwański polityk i myśliciel - stwierdził, że w jego ojczyźnie największym problemem nie są zewnętrzne ograniczenia wolności politycznej, lecz wewnętrzne i psychospołeczne, rozumiane jako niezdolność jednostki do niezależnego myślenia i działania oraz dokonywania osobistych wyborów. Zdaniem Krzysztofa Gawlikowskiego, wielu Koreańczykom czy Chińczykom trudno przyswoić sobie koncepcję praw człowieka jako przysługujących jednostce, a tym bardziej uznać je za kluczową wartość życia społecznego i politycznego ${ }^{54}$.

W społecznościach konfucjańskich, gdzie rodzina stanowiła podstawę państwa i społeczeństwa, słabo rozwijały się organizacje społeczne średniej skali, jak stowarzyszenia czy partie polityczne ${ }^{55}$. Jak uważał John K. Fairbank, w kulturze azjatyckiej trudno też o funkcjonowanie opozycji w zachodnim stylu, gdyż z oporem przyjmuje się tam ideologiczny pluralizm na poziomie zarówno grupy, jak i państwa. Opozycja natomiast zazwyczaj stara się delegitymizować aktualne władze i ustanowić nowe kierownictwo. $\mathrm{Z}$ trudem przyjmowano koncepcję rządów wielopartyjnych ze względu na towarzyszące im spory i konflikty ${ }^{56}$. Odbiegałoby to od konfucjańskich postulatów zakładających podporządkowanie rządzącym i zachowanie porządku oraz harmonii.

Utrzymywanie ładu społecznego i dobro grupy nadal są w Azji Wschodniej wartościami bardzo pożądanymi. Według konfucjanistów, jeśli ktoś naruszał je na poziomie rodziny lub wioski, zakłócał funkcjonowanie całego społeczeństwa. Dlatego mocno akcentowana była potrzeba podporządkowania wobec głowy rodziny, sołtysa wsi, przełożonego w pracy czy nawet starosty klasy szkolnej. Posłuszeństwo w stosunku do dostojników państwowych czy cesarza było wobec tego tym bardziej wymagane, a buntownicy spotykali się z potępieniem społeczeństwa ${ }^{57}$. Podkreślanie znaczenia harmonii, współpracy, konsensusu i solidarności społecznej odbiega od zachodniego nastawienia na konkurencję ${ }^{58}$. Zamiast gloryfikowania niezależności i współzawodnictwa, które mają prowadzić do wzrostu prestiżu jednostki, eksponuje się umiejętność współdziałania i podporządkowania się ${ }^{59}$. Wśród Koreańczyków nadal występują silne więzi społeczne i przekonanie, że jednostka nie może istnieć bez grupy. Oczekiwana jest wzajemna

\footnotetext{
53 K. Gawlikowski, op. cit., s. 58, 60.

54 Ibidem, s. 54-55.

55 Z. Wesołowski, op. cit., s. 191.

56 K. Gawlikowski, op. cit., s. 61, 67.

57 Ibidem, s. 34-35.

58 T. Goban-Klas, op. cit., s. 116.

59 K. Gawlikowski, op. cit., s. 57.
} 
pomoc, solidarność i poczucie odpowiedzialności względem społeczeństwa ${ }^{60}$. Obywatele Korei Południowej, chociaż mają osobistą wolność wyboru postępowania, nadal uznają istnienie tradycyjnych autorytetów, które należy bezwzględnie respektować, aby zachować osobistą i grupową harmonię ${ }^{61}$. Badanie przeprowadzone tam w 2015 roku potwierdziło, że kilka dekad funkcjonowania w Korei Południowej ustroju demokratycznego co prawda nieco osłabiło przywiązanie obywateli do sztywnej hierarchii społecznej, ale prymat dobra grupy nad interesami jednostki oraz harmonia społeczna nadal są bardzo istotne ${ }^{62}$.

Tradycyjne podejście zakładające podporządkowanie się autorytarnym władzom wymaga także innego traktowania demokracji, która opiera się przecież na równych prawach wszystkich jednostek, ich autonomii i równowadze władz. Nie współgra to z modelem zorganizowania społeczeństwa i władzy, postulowanym przez Konfucjusza $^{63}$. Krzysztof Gawlikowski stwierdza wprost, że w dawnych społeczeństwach konfucjańskich koncepcja równości wszystkich ludzi była absurdalna. Oczywistością było bowiem to, że osoby starsze i wyższe rangą były ważniejsze od młodszych i znajdujących się niżej w hierarchii. Władze nie musiały też - w przeświadczeniu poddanych - tolerować samowoli i prywaty, a raczej ograniczały je dla dobra ogółu. Uważano przy tym, że rządzący powinni o wszystkim wiedzieć ze względu na zakres ich odpowiedzialności ${ }^{64}$. W takich systemach władza państwowa miała stale kontrolować każdego obywatela, a ponadto w grupach następowała ciągła wzajemna obserwacja jej członków, co służyło eliminowaniu zachowań dewiacyjnych ${ }^{65}$. Występowała przy tym nieufność wobec obcokrajowców. Nawet kiedy podejmowali oni obronę miejscowych więźniów politycznych, spotykało się to z posądzeniem o niejasne korzyści. Z kolei, jeśli buntujący się przeciw władzy w sposób klarowny mieli rację, to ich zachowanie także spotykało się z negatywną oceną społeczną ${ }^{66}$. W opinii K. Gawlikowskiego państwa wschodnioazjatyckie wciąż charakteryzuje bardzo niski poziom tolerancji wobec zachowań i poglądów odbiegających od przyjętych norm ${ }^{67}$.

Różnice w sposobie postrzegania świata — oraz swojej roli w nim — przez przedstawicieli kultury Wschodu i Zachodu wyjaśnia w swoim dziele Richard N. Nisbett. Autor ten stwierdza, że starożytni Grecy — jako prekursorzy kultury zachodniej - mieli znaczące poczucie sprawczości, czyli przekonanie, że mogą samodzielnie decydować o swoim życiu oraz że mają swobodę wyboru działania. Łączyło się to ze świadomością

60 G. Strnad, op. cit., s. 101.

61 T. Śleziak, op. cit., s. 33.

62 E. Choi, J. Woo, Confucian Legacies and the Meaning of Democracy in South Korea: A Cultural Interpretation, „Korea Observer” 49, 2018, nr 3, s. 504-505.

63 K. Gawlikowski, op. cit., s. 37.

${ }^{64}$ Ibidem, s. 50, 59.

65 Ibidem, s. 38.

66 Ibidem, s. 51-52.

67 Ibidem, s. 62, 64. 
indywidualnej tożsamości ${ }^{68}$. W cywilizacji wschodniej natomiast ludzie nie postrzegali siebie jako wyjątkowych indywiduów, a raczej jako efekt i sumę ról pełnionych w sieci powiązań względem swojej społeczności. Podstawą szczęścia było z kolei harmonijne współistnienie z otoczeniem oraz wypełnianie wymagań urzędników reprezentujących państwo, a nie jak w przypadku Greków możliwość wykorzystywania indywidulanych uzdolnień czy zaspokajania własnych potrzeb. Poczucie indywidualnej sprawczości było natomiast zastępowane sprawczością zbiorową ${ }^{69}$. W Korei Północnej może się to obecnie przejawiać w ten sposób, że obywatele nawet jeśli nie mają możliwości podejmowania samodzielnej działalności politycznej, to odczuwają sprawczość zbiorową w polityce swego państwa na arenie międzynarodowej. Na tym gruncie ich ojczyzna - zwłaszcza według komunikatów propagandowych - udowadnia swoją potęgę i niezależność, co staje się przyczyną dumy narodowej, w której każdy obywatel ma swój udział.

\section{Współczesne znaczenie konfucjanizmu w Korei Północnej. Analiza}

Po scharakteryzowaniu podstawowych koncepcji i wartości akcentowanych w konfucjanizmie oraz ich wpływu na społeczeństwa azjatyckie, należy zastanowić się, w jakim stopniu doktryna ta przekłada się na sytuację polityczno-społeczną w Korei Północnej. Przykładowo tacy badacze, jak Selig Harrison i Thomas Hosuck Kang uważają, że długi czas trwania tamtejszego reżimu można tłumaczyć właśnie umiejętnym odwoływaniem się do tej ideologii. Jak już wspomniano, zdaniem amerykańskiego koreanisty Briana Reynoldsa Myersa, występuje tam wiele elementów, które są sprzeczne z naukami Konfucjusza i należy wobec tego negować znaczenie tych tradycji w systemie północnokoreańskim ${ }^{70}$. Władze KRLD również formalnie odcinają się od konfucjanizmu ${ }^{71}$. $\mathrm{W}$ jednym $\mathrm{z}$ tekstów propagandowych mówiono nawet o słabych klasach rządzących, które „uległy wpływom konfucjanizmu, buddyzmu i innych zgubnych, obcych ideologii”, przez co Korea stała się japońską kolonią ${ }^{72}$. Chociaż niektóre elementy północnokoreańskiej ideologii opierają się na wpływach konfucjanizmu, to nie odnosi się ona do niego wprost $^{73}$. Oficjalnie bowiem to filozofia Juche ma być podstawą funkcjonowania tego systemu ${ }^{74}$. Ponadto, tamtejsze władze głoszą odcinanie się od wpływów wszelkich religii $^{75}$. Jednak warto przywołać sytuację, kiedy Kim Il-sung w odpowiedzi na oskarżenia ze strony zagranicznych komunistów o budowanie kultu jednostki stwierdził stanowczo,

68 R.N. Nisbett, Geografia myślenia. Dlaczego ludzie Wschodu i Zachodu myślą inaczej?, przeł. E. Wojtych, Sopot 2008, s. 17.

69 Ibidem, s. 20-22.

70 B.R. Myers, Najczystsza rasa. Propaganda Korei Pótnocnej, przeł. B. Hlebowicz, Warszawa 2011, s. 78.

${ }^{71}$ N. Levi, System polityczny Korei..., s. 12.

72 B.R. Myers, op. cit., s. 62.

73 N. Levi, Correlations Between the Contemporary Ideology of the North Korean and Chosen Confucianism Values, „Krakowskie Studia Międzynarodowe” 2015, nr 3, s. 128.

74 N. Levi, Kto rządzi w Korei Pótnocnej?, Warszawa 2014, s. 115.

75 N. Levi, System polityczny Korei..., s. 51-52. 
że żyje w kulturze konfucjańskiej ${ }^{76}$. Widać wobec tego, że wpływy konfucjanizmu w Korei Północnej są kwestią bardzo zawiłą i niejednoznaczną. W celu usystematyzowania rozważań zostaną przywołane najpierw te cechy tamtejszego systemu, które są potwierdzeniem zaczerpnięcia idei konfucjańskich.

Autorytarny sposób sprawowania władzy panował w Korei przez około 1300 lat. W praktyce nie znano pojęcia demokracji czy polityki liberalnej. Dawni władcy koreańscy samodzielnie decydowali o awansach lub wygnaniu swoich współpracowników. Ten sam mechanizm panuje w przypadku rządów rodziny Kimów ${ }^{77}$. W pierwszych latach istnienia KRLD pozycja przywódcy nie była jednak tak znacząca i umacnianie jej było procesem trwającym wiele lat. Zdaniem Charlesa K. Armstronga Korea Północna początkowo była ukazywana przez rządzących nią jako część rodziny państw socjalistycznych, z kluczową rolą Związku Radzieckiego i Józefem Stalinem przewodzącym tej wspólnocie narodów. Od lat sześćdziesiątych XX wieku wraz z popularyzowaniem się ideologii Juche, zakładającej pełną niezależność, sytuacja zaczęła się jednak zmieniać i zakres „rodziny” nie obejmował już wielu narodów, a ograniczył się do obywateli KRLD z Kim Il-sungiem jako ojcem stojącym na czele i strzegącym poddanych ${ }^{78}$. Taki model mógł zostać zaadaptowany znacznie łatwiej, uwzględniając konfucjańskie tradycje w Korei. Zakorzeniony tam model rodziny w skali mini znalazł swoje odwzorowanie w skali makro, czyli ogólnonarodowej, ale już nie szerszej.

Północnokoreański system polityczno-społeczny z czasem nawiązał do tradycji, zgodnie z którą cesarz odbierał boską cześć, pełnił rolę wychowawcy narodu oraz interpretatora panujących praw. Kim Il-sung przybrał tytuł oboi Suryong, co oznaczało ojca narodu i najwyższego przywódcę ${ }^{79}$. Jego reżim miał uosabiać władzę nadaną z nieba, wprowadzającą doskonały porządek moralny. Natomiast rządy na Południu — oparte na wzorcu zachodnim - ukazywane były przez propagandę Korei Północnej jako przykład chaosu, zepsucia i podporządkowania siłom japońskim oraz amerykańskim ${ }^{80}$. Co interesujące, we wspomnianych badaniach z 2015 roku wielu obywateli Korei Południowej opowiedziało się za tym, że przeprowadzenie wolnych i uczciwych wyborów jest ważnym wyznacznikiem ustroju demokratycznego. Konieczność podziału władzy znalazła już jednak nikłe poparcie ankietowanych. Zatem w pewnym stopniu potwierdza to fakt występowania na Półwyspie Koreańskim przywiązania do postaci przywódcy, który ma szerokie kompetencje, a jego władza nie jest mocno ograniczana. Koresponduje to z tradycyjnym modelem konfucjańskim ${ }^{81}$.

Na Północy rządzący stali się niemal obiektem kultu religijnego, w którym obywatele byli wyznawcami wierzącymi w opisywane przez propagandę cuda. Zdaniem Nicolasa Leviego w tym systemie wytworzono obraz porównywalny z chrześcijańskim: Kim Il-

\footnotetext{
76 P. French, North Korea, The Paranoid Peninsula - A Modern History, London-New York 2007, s. 40.

77 N. Levi, System polityczny Korei..., s. 26.

78 Ch.K. Armstrong, Familism, Socialism and Political Religion in North Korea, „Totalitarian Movements and Political Religions" 6, 2005, nr 3, s. 383.

${ }^{79}$ N. Levi, System polityczny Korei..., s. 12.

${ }^{80}$ K. Gawlikowski, op. cit., s. 60.

81 E. Choi, J. Woo, op. cit., s. 503-504.
} 
-sunga jako Boga, Kim Jong-ila jako Jezusa oraz jego matki — Kim Jong-suk jako Maryi. Tradycje konfucjańskie polegające na synowskim oddaniu względem ojca przełożono natomiast na poświęcenie względem państwa ${ }^{82}$. W przypadku władców Korei Północnej $\mathrm{i}$ ich poddanych zaczerpnięte $\mathrm{z}$ konfucjanizmu podporządkowanie ojcu i władcy wydawało się z sobą łączyć. Rządzący jest bowiem ukazywany nie tylko jako przywódca, lecz także ojciec i opiekun narodu.

$\mathrm{W}$ dawnej Korei przekazywanie władzy z ojca na syna - mające obecnie miejsce w KRLD - również było naturalne w ramach dynastii rządzącej. To wspólnota krwi była głównym kryterium obejmowania rządów ${ }^{83}$. Według Konfucjusza od sukcesora wymagano jednak odpowiednich cech i zdolności. Przy obejmowaniu rządów przez Kim Jong-ila także zakładano, że nowy przywódca musi wykazać się nie tylko wiedzą ideologiczną, lecz także sukcesami, które potwierdzą, że potrafi on w praktyce skutecznie realizować te wytyczne. Miał dzięki temu zyskać poparcie nie tylko ze strony narodu, lecz także partii ${ }^{84}$. Profesor Moon Chung-in, komentując z kolei perspektywę przejęcia władzy przez Kim Jong-una, stwierdził, że Korea Północna jest „bardziej konfucjańska niż Konfucjusz". Zauważył przy tym, że władca musi zdobyć tam uznanie ludu, czego bardzo brakowało synowi Kim Jong-ila ${ }^{85}$. Pojawia się zatem pytanie, na ile ugruntowane było początkowo poparcie Kim Jong-una oraz czy agresywna retoryka, a także cykliczne próby militarne nie miały służyć właśnie w takim kontekście zdobywaniu legitymizacji. Udowadniał tym, że potrafi kontynuować dzieło ojca i dziadka. Pokazał też, że Korea Północna nadal budzi respekt na arenie międzynarodowej i nie obawia się światowych mocarstw. Według Ch.K. Armstronga w KRLD łatwo było o legitymizację sukcesji z ojca na syna, gdyż familizm stał się tam swego rodzaju religią polityczną. Dzięki temu też w polityce państwowej trudno zrozumiałe dla obywateli tezy marksizmu-leninizmu można było zastąpić odwołaniami do wywodzących się z konfucjanizmu wartości, takich jak: znaczenie więzów rodzinnych, wzajemna miłość i poczucie obowiązku. Takie przeświadczenie o jedności pozwalało umacniać reżim mimo trudności gospodarczych i wyzwań politycznych na arenie międzynarodowej ${ }^{86}$.

Nawiązania do konfucjanizmu występują nie tylko w odniesieniu do sprawowania rządów, lecz także w warstwie prawnej. W dawnej Korei przepisy takie miały służyć nie tyle obronie praw obywateli, ile utrzymywaniu porządku i srogiemu traktowaniu jednostek niepodporządkowanych. Dawne wzorce mogły ułatwić współczesnym przywódcom Korei Północnej zapewnienie sobie lojalności i poddania społeczeństwa. Tradycja, zgodnie z którą za zbrodnie karany był nie tylko sprawca, lecz także starsze i młodsze pokolenie, była widoczna również w systemie tworzonym przez Kim Il-sunga. Postulował on bowiem karanie osób do trzeciego pokolenia ${ }^{87}$. Praktyki takie mogły dziwić ze-

\footnotetext{
82 N. Levi, Correlations Between the Contemporary Ideology..., s. 126.

83 Ibidem, s. 125.

84 N. Levi, System polityczny Korei..., s. 58.

85 S. Crane, One More Time: North Korea is not Confucian!, www.uselesstree.typepad.com/useless_ tree/2010/10/one-more-time-north-korea-is-not-confucian.html (dostęp: 2.12.2018).

86 Ch.K. Armstrong, op. cit., s. 384.

87 N. Levi, System polityczny Korei..., s. 21, 25.
} 
wnętrznych obserwatorów, ale jak widać były one zakorzenione w tradycji koreańskiej. Należy jednak zwrócić uwagę, że współcześnie takie zabiegi mogły mieć na celu raczej odstraszanie ewentualnych naśladowców osób, które sprzeciwiały się reżimowi, niż być wyrazem kolektywizmu czy wywodzić się wprost z konfucjańskiego akcentowania roli rodziny.

Kolejnym nawiązaniem do konfucjanizmu jest podział społeczny. W okresie panowania dynastii Chosun w Korei rozpowszechnił się system klasyfikowania obywateli. W Korei Północnej wprowadzono natomiast system Songbun polegający na podzieleniu społeczeństwa na kategorie pod względem lojalności wobec władz. Każda z grup ma inne prawa i przywileje. $\mathrm{W}$ obu epokach podział ten zyskiwał jednak zrozumienie obywateli ${ }^{88}$. Istnienie klasyfikacji Songbun świadczy natomiast, że w KRLD nie ma postulowanego w komunizmie egalitaryzmu i budowy społeczeństwa bezklasowego. Nie jest to jedyna sprzeczność między konfucjanizmem a komunizmem, chociaż oba nurty często są wiązane z tym państwem.

Konfucjusz w swoich naukach wykazywał znaczenie ładu i porządku, nawet jeśli ten byłby niedoskonały. Komunizm natomiast zakładał obalenie istniejącego porządku ${ }^{89}$. Przesłaniem komunizmu było odcinanie się od przeszłości i kompletna przebudowa społeczeństwa. Tymczasem reżim północnokoreański wręcz gloryfikuje przeszłość, odwołując się do dawnych tradycji ${ }^{90}$. Konfucjanizm podkreślał też znaczenie rodziny i dominującą rolę mężczyzn. W komunizmie $\mathrm{z}$ kolei więzy rodzinne miały ulec rozluźnieniu, a jej znaczenie osłabieniu ${ }^{91}$. Korea Północna jest także państwem, w którym występuje ogromna różnica w poziomie życia między elitami a resztą społeczeństwa, podczas gdy komunizm zakładał ideę równości w posiadaniu dóbr ${ }^{92}$. Kolejna sprzeczność to fakt, że podczas gdy w KRLD występuje totalna dyktatura i podporządkowanie jednostce, komunizm postulował powszechny samorząd i dyktaturę proletariatu ${ }^{93}$. $\mathrm{Na}$ skutek upadku systemu komunistycznego na świecie, trudności gospodarczych i odchodzenia generacji z epoki Kim Il-sunga jego syn akcentował już raczej odwoływanie się do wartości nacjonalistycznych niż komunistycznych ${ }^{94}$. Należy przy tym pamiętać, że jedynie stereotypowo Korea Północna uznawana jest za państwo komunistyczne. Tak KRLD bywa też często określana w przekazach medialnych. Oficjalnie jednak - według północnokoreańskiej konstytucji - jest ona republiką socjalistyczną ${ }^{95}$. Rzeczywistość $\mathrm{w}$ tym państwie $\mathrm{w}$ wielu aspektach jest zaprzeczeniem komunizmu, nawet $\mathrm{w}$ sferze funk-

${ }^{88}$ N. Levi, Correlations Between the Contemporary Ideology ..., s. 123-124.

89 F. Engels, Zasady komunizmu, s. 11, http://1917.net.pl/sites/default/files/Engels\%20-\%20Zasady\%20 Komunizmu.pdf (dostęp: 3.12.2018).

90 R.E. Kelly, Guest Post: Dave Kang - „Confucian North Korea”, www.asiansecurityblog.wordpress. com/2012/07/31/guest-post-dave-kang-confucian-north-korea (dostęp: 1.12.2018).

91 A. Kołłontaj, Rodzina w ustroju robotniczym, s. 3-5, http://docplayer.pl/16468848-Aleksandra-kollontaj-rodzina-w-ustroju-robotniczym.html (dostęp: 4.12.2018).

92 F. Engels, op. cit., s. 9-11.

93 Ibidem, s. 10.

${ }_{94}$ N. Levi, Kto rządzi w Korei..., s. 115-116.

95 DPRK's Socialist Constitution, www2.law.columbia.edu/course_00S_L9436_001/North\%20Korea\%20 materials/98091708.html (dostęp: 10.05.2019). 
cjonowania tamtejszej gospodarki, która w ostatnich latach $\mathrm{w}$ coraz większym stopniu opiera się na działalności prywatnych przedsiębiorców. Wykluczanie się przesłanek komunizmu i konfucjanizmu nie powinno być zatem argumentem za brakiem znaczenia nauk Konfucjusza dla współczesnego funkcjonowania reżimu północnokoreańskiego, gdyż jak widać obecnie wywierają tam zdecydowanie większy wpływ niż ideały Karola Marksa.

Wracając jednak do kluczowego toku rozważań, należy zauważyć, że Kim Jong-il w swoich publikacjach odnosił się do znaczenia honoru, nauki, sumiennego wykonywania powierzonych zadań czy wiary w politykę władz. Nadal w Korei Północnej widoczne jest akcentowanie takich wartości, jak: lojalność, rodzina i patriarchat, które wywodzą się z konfucjanizmu ${ }^{96}$. Nawet tak autorytarny przywódca, jak Kim Jong-il, wykazywał szacunek dla starszych ludzi ze szczytów północnokoreańskich władz i generalicji. Pomimo zaawansowanego wieku osoby te niezmiennie pełniły zajmowane wcześniej ważne stanowiska państwowe ${ }^{97}$. Podobnie jest w przypadku okresu rządów Kim Jong-una, czego przykładem była chociażby wieloletnia kariera polityczna Kim Yong-nama, czyli przewodniczącego Najwyższego Zgromadzenia Ludowego. Wpływy konfucjanizmu na charakter relacji interpersonalnych były widoczne także w konstytucji z 1972 roku. Artykuł 78 stwierdzał tam, że rodziny są podstawowymi komórkami w ciele społeczeństwa, a państwo musi je chronić ${ }^{98}$. Nadal zauważalne są również tradycje, zgodnie z którymi ciągłość rodu zapewniają synowie i oni muszą się zaopiekować rodzicami w okresie starości ${ }^{99}$.

Inaczej sytuacja przedstawiała się $\mathrm{w}$ przypadku postrzegania ról społecznych poszczególnych płci. Jest to pierwsze z zaprzeczeń wobec konfucjanizmu, które będą niżej ukazane. Ideologia ta zakładała rozróżnienie pierwiastków yin i yang. Męski pierwiastek yang uznawany był za aktywny i miał zdominować bierny pierwiastek kobiecy. Przekładało się to na poglądy, według których obowiązki kobiet miały ograniczać się do pełnienia zadań żony i matki. W Korei Północnej od czasów rządów Kim Il-sunga, pomimo domniemanej dominacji mężczyzn w życiu społecznym, kobiety miały możliwość sprawowania nawet funkcji ministerialnych ${ }^{100}$. Ponadto, jeśli około $10 \%$ mężczyzn służy $\mathrm{w}$ armii, to lukę na rynku pracy musiały zapełnić kobiety, co też nie współgra $\mathrm{z}$ ideami konfucjanizmu ${ }^{101}$. W okresie klęski głodu z połowy lat dziewięćdziesiątych XX wieku również kobiety utrzymywały rodziny, starając się dorabiać na przykład poprzez handel.

96 N. Levi, Kto rządzi w Korei..., s. 115-116.

97 N. Levi, The Importance of Confucian values to Kim Jong Il's System. A comparison with Kim Il Sung's System, s. 12, www.sinonk.com/wp-content/uploads/2012/08/levi-on-kim-jong-il-confucianism-icks-2012. pdf (dostęp: 4.12.2018).

98 Korea (Democratic People's Republic of)'s Constitution of 1972 with Amendments through 1998, s. 15, https://www.constituteproject.org/constitution/Peoples_Republic_of_Korea_1998.pdf?lang=en (dostęp: 10.05.2019).

${ }_{99}$ B. Demick, Światu nie mamy czego zazdrościć. Zwyczajne losy mieszkańców Korei Pótnocnej, przeł. A. Nowakowska, Wołowiec 2011, s. 20.

100 N. Levi, System polityczny Korei..., s. 22.

101 B. Demick, op. cit., s. 57. 
Mężczyźni pozostający na państwowych posadach prawie nie otrzymywali wtedy wyna$\operatorname{grodzenia}^{102}$.

W bardziej istotny sposób idei państwa konfucjańskiego zaprzecza jednak militaryzacja Korei Północnej. Konfucjaniści wyrażali zdecydowaną niechęć do działań zbrojnych. Z naturalnych względów stanowią one naruszenie harmonii i powodują chaos. Wszelkie sprawy związane $\mathrm{z}$ wojskowością postrzegano jako zło konieczne, a żołnierzy uważano za najniższą grupę społeczną. Powołanie do armii traktowano jako nieszczęście. Urzędnicy konfucjańscy z odrazą odnosili się do agresji i przemocy. Wśród działań zbrojnych preferowano te o charakterze obronnym, jak budowa i umacnianie fortyfikacji. Każdy konflikt starano się rozwiązywać przy pomocy dyplomacji ${ }^{103}$. Przez wieki władcy koreańscy nie angażowali się bezpośrednio w działania wojenne, będąc wzorem moralnym. Manifestowanie dokonań na gruncie militarnym zapoczątkowane przez Kim Il-sunga można wobec tego uznać za oddalanie się od wizerunku władcy koreańskiego, jaki wykształcił się w tamtejszej tradycji ${ }^{104}$. Kolejna sprzeczność to fakt, że żołnierze stawiani są jako wzór dla obywateli ${ }^{105}$. Poprzez ciągłe prowokacje i groźby państwo to niszczy ład i spokój międzynarodowy, łamiąc jeden z podstawowych postulatów konfucjanizmu.

Według B.R. Myersa przekonanie o konfucjańskim modelu państwa, zgodnie z którym wódz miał odgrywać rolę ojca narodu, Partia Pracy Korei być symbolem matki, a obywatele dziećmi, także jest niezasadna. Uważa on bowiem, że Kim Il-sung bardziej utożsamiany był z figurą matki niż patriarchy ${ }^{106}$. Autor ten stwierdza, że nawet kiedy władca ten był określany mianem ojca-przywódcy, to nie było w tym nic konfucjańskiego czy patriarchalnego. Był on raczej ukazywany jako troskliwy i kochający ojciec narodu. Sam Kim Jong-il również pisał o nim, że jak czuła matka dbał o swój lud. Kolejnym zaprzeczeniem konfucjanizmu ma być to, że Kim Il-sung traktował swego syna z wielkim respektem, a nawet pisał na jego cześć panegiryk. Takie zachowanie miało być niezrozumiałe na przykład dla osób z Korei Południowej, gdzie tradycje konfucjańskie rzeczywiście są podtrzymywane ${ }^{107}$.

Należy również zauważyć, że zgodnie z tą ideologią jeśli rządzący postępował niewłaściwie, obowiązkiem jego otoczenia było zwrócenie mu na to uwagi, a jeżeli nie przynosiło to skutku, powinno się dążyć do jego usunięcia ${ }^{108}$. W znaczący sposób odbiega to od sytuacji w Korei Północnej, gdzie sprzeciw wobec przywódcy pociągałby za sobą spore ryzyko nawet dla osób ze szczytów władz. Na Północy nie praktykuje się również dawnych rytuałów, jak ma to miejsce na Południu. Szacunek wobec rodziców jest

102 Ibidem, s. 184.

103 Z. Wesołowski, op. cit., s. 189.

104 N. Levi, System polityczny Korei..., s. 23.

105 B.R. Myers, op. cit., s. 69.

106 Ibidem, s. 35.

107 Szerzej o kultywowaniu konfucjańskich tradycji w dzisiejszej Korei Południowej zob. S.H. Kim, North Korea's Continuing Survival: Confucianism and Self-Reliance, [w:] Economic Sanctions Against a Nuclear North Korea. An Analysis of United States and United Nations Actions since 1950, red. S.H. Kim, S. Chang, North Carolina-London 2007, s. 151-152.

108 S. Crane, op. cit. 
natomiast eksponowany niemal we wszystkich kulturach. Należy jednak zauważyć, że konfucjanizm również mówił o tym, że ojciec — chociaż mający autorytet i podejmujący decyzje - powinien otaczać troską dzieci. Ponadto, mimo że propaganda ukazuje przywódców jako troszczących się o obywateli, to jednocześnie pokazywani byli oni jako władczy i nieprzejednani względem innych państw. Istotnym zaprzeczeniem konfucjanizmu jest natomiast fakt, że Konfucjusz nie wywyższał żadnej rasy ponad inne, co bardzo odbiega od tez promowanych przez północnokoreańskie władze ${ }^{109}$. Nacjonalizm zyskuje bowiem w tym państwie ogromne znaczenie. Kim Jong-un wspominał na przykład w przemówieniu z 2012 roku, że jego ojciec powtarzał: „Na świecie nie ma narodu lepszego od naszego"110. Z kolei w ostatnich latach jeden z północnokoreańskich dzienników partyjnych pisał: „Monoetniczność (tanilsong) jest czymś, z czego nasz naród i żaden inny na ziemi - może być dumny. Wstydu i gniewu wywołanego w narodzie hasłami o wieloetnicznym, wielorasowym społeczeństwie, nie da się powstrzymać [...], skaziłoby to krew naszego ludu"111. Według wielu analityków to właśnie nacjonalizm akcentujący wyższość Koreańczyków wobec innych narodów może być zatem podstawą funkcjonowania tamtejszego reżimu i legitymizacji władz. Takie nastawienie trudno $\mathrm{z}$ kolei pogodzić z założeniami konfucjanizmu.

\section{Podsumowanie}

Tradycje konfucjańskie przez wieki w znaczącym stopniu kształtowały system polityczno-społeczny oraz mentalność mieszkańców Półwyspu Koreańskiego. Jak wynika z poczynionej analizy, nie można jednak określać Korei Północnej jako państwa stricte konfucjańskiego, gdyż wykazano wiele zaprzeczeń wobec założeń tej ideologii. Wydaje się natomiast, że również negowanie wpływu koncepcji Konfucjusza na obecną sytuację w KRLD nie jest właściwe. Brak tradycji oddolnej działalności politycznej oraz niechęć do buntu mogą być czynnikami blokującymi perspektywy przemian, zwłaszcza jeśli uwzględnić opisane zakorzenione $\mathrm{w}$ tradycji koreańskiej podporządkowanie względem autorytetów, a szczególnie wobec autorytarnego władcy. Ewentualny bunt wobec władz wydawałby się bardziej prawdopodobny, gdyby miał być skierowany wobec reżimu znajdującego się pod obcymi wpływami. Natomiast w Korei Północnej władza rodziny Kimów zasadza się nie tylko na wspomnianym konfucjańskim postulacie podporządkowania autorytetom, lecz także na tym, że dzięki podsycaniu tez nacjonalistycznych, naród ma być odwzorowaniem konfucjańskiej rodziny z ojcem (przywódcą) obdarzającym ich troską. Powoduje to, że sprzeciw wobec władz byłby nie tyle wyrazem walki o wolność, ile rodzajem zdrady kultywowanych wartości i sprzeciwem wobec reżimu

109 B.R. Myers, op. cit., s. 78.

110 W.J. Dziak, K. Sajewski, Korea Północna. Wewnętrzne wektory trwania, Aneks 6 - Przemówienie Kim Dzong Una Robotnicy całego świata, łączcie się! Będziemy wcielać w życie patriotyzm Kim Dzong Ila dla przyspieszenia procesu budowy bogatej i prężnej Ojczyzny. Spotkanie z kierowniczymi kadrami KC Partii Pracy Korei, Warszawa 2016, s. 281.

111 B.R. Myers, op. cit., s. 60. 
broniącego - według własnych deklaracji - koreańskiej tradycji oraz dobra i bezpieczeństwa, gloryfikowanego bardziej niż w innych narodach, przed obcym zagrożeniem. $\mathrm{W}$ przypadku tego państwa mamy więc do czynienia z pomieszaniem pozornie wykluczających się ideologii. Jednak sprzeczność nacjonalizmu z wytycznymi konfucjanizmu wcale nie przeszkadza władzom północnokoreańskim, jeśli zaszczepianie w obywatelach idei narodowych jest przydatne dla trwania reżimu.

Chociaż ideologia Juche zakłada odrzucenie tradycji i przeszłości w imię budowania rewolucji, nie jest to dla tamtejszych władz przeszkodą w zachowaniu ugruntowanych w społeczeństwie koreańskim tych wartości konfucjańskich, które mogą legitymizować reżim. Zatem nawiązania do konfucjanizmu były i są instrumentalnie wykorzystywane w Korei Północnej przez aparat władzy. Stanowią też grunt pod przekazy propagandowe wychwalające wielkość przywódców oraz ich poświęcenie dla ojczyzny. Wobec tego wybrane wpływy konfucjanizmu — pomimo zauważalnych licznych zaprzeczeń względem tej ideologii - mogą być jednym z powodów utrzymywania się reżimu rodziny Kimów od siedemdziesięciu lat. Może to być czynnik umacniający rządy Kim Jong-una także w nadchodzących latach.

\section{Bibliografia}

Armstrong Ch.K., Familism, Socialism and Political Religion in North Korea, „Totalitarian Movements and Political Religions" 6, 2005, nr 3.

Choi E., Woo J., Confucian Legacies and the Meaning of Democracy in South Korea: A Cultural Interpretation, „Korea Observer” 49, 2018, nr 3.

Crane S., One More Time: North Korea is not Confucian!, www.uselesstree.typepad.com/useless_tree/2010/10/ one-more-time-north-korea-is-not-confucian.html (dostęp: 2.12.2018).

Demick B., Światu nie mamy czego zazdrościć. Zwyczajne losy mieszkańców Korei Pólnocnej, przeł. A. Nowakowska, Wydawnictwo Czarne, Wołowiec 2011.

DPRK's Socialist Constitution, www2.law.columbia.edu/course_00S_L9436_001/North\%20Korea\%20materials/98091708.html (dostęp: 10.05.2019).

Dziak W.J., Sajewski K., Korea Pólnocna. Wewnętrzne wektory trwania, Aneks 6 - Przemówienie Kim Dzong Una Robotnicy całego świata, łączcie się! Będziemy wcielać w życie patriotyzm Kim Dzong Ila dla przyspieszenia procesu budowy bogatej i prężnej Ojczyzny. Spotkanie z kierowniczymi kadrami KC Partii Pracy Korei, Instytut Studiów Politycznych PAN, Warszawa 2016.

Engels F., Zasady komunizmu, http://1917.net.pl/sites/default/files/Engels\%20-\%20Zasady\%20Komunizmu. pdf (dostęp: 3.12.2018).

French P., North Korea, The Paranoid Peninsula - A Modern History, Zed Books, London-New York 2007.

Gawlikowski K., Jednostka i władza w cywilizacji wschodnioazjatyckiej, [w:] Korea: doświadczenia i perspektywy, red. K. Gawlikowski, E. Potocka, Wydawnictwo Adam Marszałek, Toruń 2002.

Goban-Klas T., Historia i współczesność Korei. Od pustelniczego królestwa do azjatyckiego tygrysa, Wydawnictwo Adam Marszałek, Toruń 2006.

Kelly R.E., Guest Post: Dave Kang — „Confucian North Korea”, www.asiansecurityblog.wordpress.com/2012/07/31/ guest-post-dave-kang-confucian-north-korea (dostęp: 1.12.2018).

Kim S.H., North Korea's Continuing Survival: Confucianism and Self-Reliance, [w:] Economic Sanctions Against a Nuclear North Korea. An Analysis of United States and United Nations Actions since 1950, red. S.H. Kim, S. Chang, McFarland \& Company Inc., Publishers, Jefferson, North Carolina-London, 2007. 
Kołłontaj A., Rodzina w ustroju robotniczym, http://docplayer.pl/16468848-Aleksandra-kollontaj-rodzinaw-ustroju-robotniczym.html (dostęp: 4.12.2018).

Korea (Democratic People's Republic of)'s Constitution of 1972 with Amendments through 1998, https://www. constituteproject.org/constitution/Peoples_Republic_of_Korea_1998.pdf?lang=en (dostęp: 10.05.2019).

Kukułka J., Teoria stosunków międzynarodowych, Wydawnictwo Naukowe Scholar, Warszawa 2000.

Lee H., Kapitalizm konfucjański. Koreańska droga rozwoju, Wydawnictwo Adam Marszałek, Toruń 2011.

Lee K.K., Confucian Tradition in the Contemporary Korean Family, [w:] Confucianism and the Family: A Study of Indo-Tibetan Scholasticism, red. W.H. Slote, G.A. De Vos, State University of New York Press, New York 1998.

Levi N., Correlations Between the Contemporary Ideology of the North Korean and Chosen Confucianism Values, „Krakowskie Studia Międzynarodowe” 2015, nr 3.

Levi N., Kto rządzi w Korei Pótnocnej?, Wydawnictwo Dialog, Warszawa 2014.

Levi N., The Impact of Confucianism in South Korea and Japan, „Acta Asiatica Varsoviensia” 2013, nr 26.

Levi N., The Importance of Confucian values to Kim Jong Il's System. A comparison with Kim Il Sung's System, www.sinonk.com/wp-content/uploads/2012/08/levi-on-kim-jong-il-confucianism-icks-2012.pdf (dostęp: 4.12.2018).

Levi N., System polityczny Korei Pólnocnej. Aspekty kulturowe, Wydawnictwo Askon, Warszawa 2013.

Myers B.R., Najczystsza rasa. Propaganda Korei Pótnocnej, przeł. B. Hlebowicz, Wydawnictwo Naukowe PWN, Warszawa 2011.

Nakamura H., Systemy myślenia ludów Wschodu. Indie, Chiny, Tybet, Japonia, przeł. M. Kanert, W. Szkudlarczyk-Brkić, red. P.P. Wiener, Wydawnictwo Uniwersytetu Jagiellońskiego, Kraków 2005.

Nisbett R.N., Geografia myślenia. Dlaczego ludzie Wschodu i Zachodu myśla inaczej?, przeł. E. Wojtych, Wydawnictwo Smak Słowa, Sopot 2008.

Strnad G., Korea. Polityka Poludnia wobec Pólnocy w latach 1948-2008. Zmiana i kontynuacja, Instytut Zachodni, Poznań 2014.

Śleziak T., The Role of Confucianism in Contemporary South Korean Society, „Rocznik Orientalistyczny” 66, 2013, z. 1.

Wesołowski Z., Konfucjańskie podstawy porządku społecznego i zjawisko „twarzy”, [w:] Zrozumieć Chińczyków. Kulturowe kody społeczności chińskich, red. E. Zajdler, Wydawnictwo Akademickie Dialog, Warszawa 2011.

\title{
The role of Confucian traditions in strengthening the contemporary political regime of the Democratic People's Republic of Korea
}

\author{
Keywords: North Korea, Confucianism, regime, Kim Jong-un
}

\section{Summary}

In Asian countries authoritarian relationships have been noticeable for centuries not only on political but also on social grounds. The teachings of Confucius were important in this aspect. According to many authors, they still exert a significant influence in North Korea and have an impact on the durability of Kim Jong-un. However, there are also opinions that it is a big mistake to describe this country as Confucian. For this reason the aim of this article is to show the real meaning of this ideology in North Korea. This will be done by demonstrating similarities of the present situation to the principles of Confucianism, as well as denials of the guidelines of this ideology. As a result, this will allow the author to analyze how Confucian traditions can determine the future of the regime in Pyongyang. 